\title{
CAN FAMILY OWNERSHIP STRENGTHEN THE RELATIONSHIP BETWEEN INTELLECTUAL CAPITAL AND PERFORMANCE IN ASEAN HIGH-TECH FIRMS?
}

\author{
Bima Cinintya Pratama* \\ Faculty of Economics and Business, Universitas Muhammadiyah Purwokerto \\ Maulida Nurul Innayah \\ Faculty of Economics and Business, Universitas Muhammadiyah Purwokerto
}

\begin{abstract}
This study investigates the positive relationship between intellectual capital and firm performance. It examines whether family ownership can strengthen the relationship between intellectual capital and firm performance of firms in high-technology industries in ASEAN. The data was collected from the BvD OSIRIS database and company annual reports from 2008-2014 and conducted on five countries in ASEAN, namely Indonesia, Malaysia, Philippines, Singapore, and Thailand. The final sample used in this study consists of a total of 1,310 observations. This study uses panel data regression model analysis, i.e. fixed effect regression and random effect regression. The results showed that intellectual capital has a positive relationship with financial performance. The result proved the role of intellectual capital in increasing firm finances and its importance as one of the primary resources in competing in the AEC challenges and as the firm's primary driver for the firm's success. It is not found in the relationship between intellectual capital and market performance. In the interaction relationship, the result is contrary to the alignment effect that becomes our previous prediction. The result is consistent with the entrenchment effect and indicates that family ownership can weaken the relationship between intellectual capital and financial performance. There is no evidence about the relationship between the interaction of intellectual capital and family ownership on market performance.
\end{abstract}

Keywords: Intellectual Capital, Family Ownership, Financial Performance, Market Performance.

Received: 20 June 2019

Accepted: 26 August 2021

https://doi.org/10.33736/ijbs.4286.2021

\section{INTRODUCTION}

The ASEAN Economic Community (AEC) issue started to be discussed by many since the ASEAN Economic Community Blueprint (2008), the result of the 13th ASEAN Summit in Singapore in 2007, was published. AEC has been enacted actively by the end of 2015. Although the AEC can improve ASEAN to be more dynamic and competitive, it will also make the competition between firms inside the ASEAN region become increasingly competitive. This condition requires the firm to utilize its resources more effectively and efficiently to create value-added and compete on the AEC.

\footnotetext{
- Coressponding author: Faculty of Economics and Business, Universitas Muhammadiyah Purwokerto, Jl. KH. Ahmad Dahlan, Dukuhwaluh, Purwokerto, Jawa Tengah, Indonesia, 53182; Tel: +62281636751; Email: pratamabima@gmail.com or bimacinintyapratama@ump.ac.id
} 
According to the resource-based theory, intellectual capital (hereinafter referred to as IC) is a resource that serves as the core of value creation and competitive advantage for a firm (Barney, 1991). Chen et al. (2005) and Wang (2008) explained that the sustainable competitive advantages from IC would make the firm win the competition with other firms and create added value to contribute to the firm's success. Previous studies have attempted to examine the relationship between IC and the firm's performance, but the results are still inconsistent. The studies from Firer and Stainbank (2003), Chen et al. (2005), Tan et al. (2007), and Clarke et al. (2011) found that IC is positively related to the firm financial performance and market performance. Meanwhile, the studies from Firer and Williams (2003), Chan (2009), and Maditinos et al. (2011) could not find any evidence to support the relationship between IC and firm performance. Due to the inconsistency in those results of previous studies and also because of the limited number of studies that have been conducted on developing countries at the regional level, particularly in ASEAN, this study aims to examine the positive impact of IC on the performance of the firms operating in the high-technology industry in ASEAN. It is also interesting to understand the role of intellectual capital on firm performance before the enactment of the ASEAN Economic Community to predict the importance of intellectual capital as one of the primary resources in competing in the era of AEC.

This study also tried to find a new variable that may strengthen the relationship between IC and firm performance to fill the research gap from previous research inconsistency. Grant (1996) explained that the utilization of competitive advantages of IC could not be maximized without the presence of good organization and allocation of the resource. Keenan and Aggestam (2001) stated that the attitudes and skills of substantial shareholders are the keys of firm management, including in utilising the firm's IC. The study from Claessens et al. (2000) and Carney and Child (2013) found that firms in East Asia, including ASEAN, are firms which ownership is concentrated predominantly on family ownership. Meanwhile, the studies from Anderson and Reeb (2003), Ng (2005), and Essen et al. (2015) showed that the firms with family ownership are more efficient in controlling and supervising firm activities, so their performance is higher. The second objective of this study is to examine whether family ownership is able to strengthen the relationship between IC and firm performance.

This study uses a monetary measurement, namely value-added intellectual coefficient (VAIC) developed by Pulic (2000; 2004), to measure a firm's IC. Data obtained from the OSIRIS database. The samples of this study are the firms engaged in high technology industries located in five ASEAN countries, namely Indonesia, Malaysia, the Philippines, Singapore and Thailand, from 2008 to 2014. The high technology industry was selected for this study because it relies on IC for its activities. The firms in this industry tend to invest substantially in the IC. This is in line with Bontis (2001) and Hermans and Kauranen (2005), who states that the high-technology industry is appropriate and interesting to be the object of IC research. This study uses a panel data regression model (i.e. fixed effect and random effect regression).

This study has several contributions in both theoretical and business fields. First, this study contributes to the theoretical field by testing the moderating effect of family ownership to strengthen the relationship between IC and firm performance. It is interesting to understand this relationship considering the role of family ownership because this ownership type is a common form of ownership in ASEAN firms. Second, this study contributes to the practice by understanding the role of intellectual capital on firm performance before the period of ASEAN Economic 
Community enactment so that it can predict the importance of intellectual capital as one of the primary resources in competing in the AEC challenges later on as well as encouraging performance improvement. Third, this study can be a consideration for decision-makers to review the effect of family ownership that can reduce the effect of intellectual capital on performance.

The results showed that intellectual capital has a positive relationship with financial performance. This result indicates that intellectual capital can give a higher financial performance for the firms. The result proved the role of intellectual capital in increasing firm financial performance before the period of ASEAN Economic Community enactment. Therefore, it implies that when AEC is enacted, the importance of intellectual capital as one of the primary resources in competing in the AEC challenges and as the firm's primary driver for future success is already predicted. This is not found in the relationship between intellectual capital and market performance. In the interaction relationship, the result is contrary to the alignment effect that becomes our previous prediction. The result is consistent with the entrenchment effect and indicates that family ownership can weaken the relationship between intellectual capital and financial performance. It means that the firms' family ownership could lead to inefficient and ineffective in supervising and monitoring the activities undertaken by management, including in supervising the use of intellectual capital resources optimally, which will cause the firm to be not optimal in utilizing the intellectual capital to achieve better performance. It implies that the firms with family ownership should strengthen the governance so that the entrenchment effect of the family ownership could be minimized. There is no evidence about the relationship between the interaction of intellectual capital and family ownership on market performance.

\section{LITERATURE REVIEW AND HYPOTHESES DEVELOPMENT}

\subsection{Resource-based theory $(\mathrm{RBT})$}

RBT provides a vital framework to explain and predict an underlying for competitive advantage and firm performance (Barney et al., 2011). RBT explained that creating sustainable competitive advantage is closely related to the firm's ability to maintain valuable, rare, and irreplaceable resources and allocate and deploy these resources effectively (Barney, 1991).

Kozlenkova et al. (2014) explained that the basic logic of this theory is based on two fundamental assumptions regarding the firm resources and explain how these resources can generate sustainable competitive advantage and why some firms can consistently outperform other firms. First, the firm has different resources, even within the same industry (Peteraf \& Barney, 2003). Assumptions regarding the heterogeneity of these resources show that some firms have better expertise in completing certain activities because they have unique resources (Peteraf \& Barney, 2003). Second, differences in resources will remain due to difficulties in exchanging resources between firms (resource immobility assumption), which will lead to the advantage of the heterogeneity of these resources continuing to occur from time to time (Kozlenkova et al., 2014).

Valuable, Rare, imperfectly imitable, Organization (VRIO) characteristics show four conditions to assess how potential a resource will be able to generate sustainable competitive advantage (Kozlenkova et al., 2014). The following are VRIO characteristics: 
a. Valuable

A firm resource can be said as valuable if the resource enables firms to develop and implement strategies that can reduce corporate costs and increase the firm revenue more than when the resources are not present.

b. Rare

Rare resources are resources that are controlled only by a small number of competing firms. Suppose these resources are valuable but not rare. In that case, utilising those resources will produce competitive equality because the other firms that also have these resources can utilize them.

c. Imperfectly imitable

Imperfectly imitable resources cannot be obtained through duplication or direct substitution by firms that do not have them.

d. Organization

The firm resources should be organized so that the potential competitiveness of those resources can be utilized maximally. Organizations act as adjustment factors that allow the firms to use the benefits contained in the resourcefully.

According to RBT, IC has great potential to meet the VRIO characteristics to create a competitive advantage for the firm, according to the explanation above. By the competitive advantage from IC, firms can use it to compete in a competitive market and achieve optimal performance.

\subsection{Value Added Intellectual Coefficient (VAIC)}

Pulic $(2000 ; 2004)$ build a model to measure how components of IC can create values and competitive advantage for the firm. The model is called Value Added Intellectual Coefficient (VAIC). VAIC offers a relatively simple quantitative approach based on the firm accounting information to measure the IC and its components (Pulic, 2000). The essential concept of VAIC is the corporate intellectual ability that refers to the efficiency of the whole value creation created by two resources, namely IC resources and physical resources that work simultaneously in the business environment (Pulic, 2004). The basic assumption of VAIC is that the IC itself cannot operate independently without the support of financial and physical capital (Pulic, 2004). VAIC combines several components or elements, namely Human Capital Efficiency, Structural Capital Efficiency, and Physical Capital Efficiency.

VAIC model started by calculating a firm's ability to create value-added (VA). VA is the difference between the output (OUT) and the input (IN) and is formulated in the following equation:

$$
\mathbf{V A}=\mathbf{O U T}-\mathbf{I N}
$$

The output (OUT) represents revenue that covers all products and services sold by the firm. Input (IN), including all expenses incurred to generate revenue except for employee costs. It is important to note that in this model, employee costs are not included in the IN. Due to its active role in value creation, intellectual potential represented by employee costs is not counted as an expense. Thus, 
an essential aspect of the VAIC method is by treating the employee as a value-creating entity. The calculation resulted in VA, which reveals the wealth of the firm in the period. VA is influenced by both the efficiency of human capital (HC) and structural capital (SC).

The first relationship of VA is between VA and HC, known as Human Capital Efficiency (HCE). $\mathrm{HCE}$ shows the ability of $\mathrm{HC}$ to create value in the firm. Similarly, when HCE is compared to some firms, HCE serves as an indicator of the quality of human resources owned by the firm and their ability to generate VA for each unit of money spent on the HC. Pulic (2000) argues that the total cost of salaries and wages can be an indicator of $\mathrm{HC}$ because the market determines the salaries and wages as a result or impact of the firm performance, then it would be logical if the success of the HC declared with the same criteria. The relationship between VA and HC can be formulated as follows:

$$
\text { HCE }=\text { VA } / \text { HC }
$$

The second relationship is Structural Capital Efficiency (SCE), which shows the contribution of structural capital (SC) in value creation. In the VAIC model, SC is calculated by subtracting VA with $\mathrm{HC}$. The smaller the contribution of $\mathrm{HC}$ in value creation, the more significant the contribution of SC. In other words, the relationship between VA and SC are calculated in different ways because $\mathrm{HC}$ and $\mathrm{SC}$ are in inverse proportion in the firm value creation. SCE measures the amount of SC required for one unit of VA's money and serves as an indication of how SC success in value creation. Unlike HCE, VA is the denominator for SCE. Thus, the relationship between VA and SC is calculated by the following equation:

$$
\mathrm{SCE}=\mathrm{SC} / \mathrm{VA}
$$

The third relationship of VA is with the physical capital (CE), known as the Capital Employed Efficiency (CEE). CEE is an indicator for VA created by a unit of physical capital. CEE can be formulated as follows:

$$
\mathrm{CEE}=\mathrm{VA} / \mathrm{CE}
$$

Pulic $(2000 ; 2004)$ assumes that if one unit of CE generates greater profits in the firm than others, the firm is better at utilizing its CE. Thus, better utilization of CE is also part of the firm's IC. Compared to a group of firms, CEE indicates a firm's intellectual ability to utilize physical capital more optimally.

The last step is calculating the firm overall intellectual ability. This calculation is the sum of the coefficients mentioned earlier. This resulted in a new and unique indicator, namely:

$$
\mathrm{VAIC}=\mathrm{HCE}+\mathrm{SCE}+\mathrm{CEE}
$$


Several studies and literature showed that VAIC is a promising measurement mechanism for measuring IC. Firer and Williams (2003) have mentioned the advantages of the VAIC method, namely VAIC provide a consistent and standardized measurement basis that allow effective comparative analysis between firms and between countries; Data used in VAIC calculation is based on data that has been audited in the financial statements so that the calculation will be more objective. In addition, VAIC also has been used in several studies with the different industry settings listed in the various countries stock exchanges, for example, the Johannesburg Stock Exchange, Taiwan Stock Exchange, Singapore Exchange, Hong Kong Stock Exchange, Athens Stock Exchange and the Australian Stock Exchange (Firer \& Williams, 2003; Chen et al., 2005; Tan et al., 2007; Chan, 2009; Maditinos et al., 2011; Clarke et al., 2011). The literature also indicates that the VAIC has been used in the study of developing countries, like Taiwan, Greece, and South Africa, to examine the relationship between IC and firm performance (Chen et al., 2005; Maditinos et al., 2011; Firer \& Williams, 2003).

\subsection{Family Ownership}

Several studies examining the ownership structure show that family ownership is the dominant ownership structure in East Asia firms. Claessens et al. (2000) found that family ownership reached more than half of the ownership in East Asia countries, including ASEAN. Meanwhile, a recent study by Carney and Child (2013) also stated that although much has changed since Claessens et al. (2000) study, family ownership is still the most dominant form of ownership structure in East Asia.

It is a vast impact on the agency conflict between owners and managers. New insights about this ownership structure require careful analysis to determine the consequences of family ownership on firm performance. Wang (2006) describes two views about the position of family ownership structure in supervising the activities undertaken by the management, namely the entrenchment effect and alignment affect views.

The entrenchment effect is a view which stated that concentrated ownership would provide incentives for controlling shareholders to expropriate the wealth of other shareholders (Fama \& Jensen, 1983; Morck et al., 1988; Shleifer \& Vishny, 1997). In other words, the entrenchment effect revealed that the family as controlling shareholders probably would take personal advantage of the firm at the expense of minority shareholders. Therefore, the entrenchment effect predicts that the family ownership in the firm may be inefficient and ineffective in supervising the activities undertaken by management, including in supervising the utilization of resources to the maximum use, which will cause the firm to be not optimal in its value creation.

The alignment effect is explained contrary to what is described by the entrenchment effect. According to the alignment effect, the interests of the family and other shareholders are aligned because of the large number of shares owned by the family and its long-term existence in the firm. Based on the alignment effect, family members have a lower tendency to behave opportunistically because they will be in the firm for the long-term because they desire to bequeath the firm to the next generation and the desire to keep the family name good picture. Due to the family welfare is closely related to the firm's value, the family will have more significant incentives to monitor employee activity (Anderson \& Reeb, 2003). 
Consistent with the alignment effect, previous studies have shown how a family firm can positively impact corporate behaviour to achieve better performance. Anderson and Reeb (2003) showed that family firms have a better performance than non-family firms, as measured by financial performance and market performance. According to Anderson and Reeb (2003), this is because the family enterprise is more efficient in supervising the firm management activities than firms that are widely held by the public. In addition, long-term bonds that generally exist in a family firms means that external agents, such as providers of funds or lender, have developed the family business with family owners in the long-term (Anderson \& Reeb, 2003). This causes the external agents to perceive the family's reputation that will bring economic consequences not only on the lifetime of the original owner or the family's first generation, but it would last to the descendants or heirs of the family. It also shows that compared with non-family firms, family firms will tend to maintain and maximize their wealth for a very long time.

Several other studies also support the alignment effect, such as the study from $\mathrm{Ng}$ (2005) in firms listed in the Hong Kong Stock Exchange (HSE), which showed that the family ownership in Hong Kong and its collectivist culture would have a positive impact on firm performance. In addition, Isakov and Weisskopf (2014) showed that in the Swiss Stock Exchange, the firm with family ownership is more profitable than the firm whose ownership is dispersed or has a non-family ownership structure and also shows the relationship between family ownership and market value. These findings indicate a positive relationship between family ownership and corporate governance, which will ultimately positively impact firm performance.

\subsection{Intellectual Capital and Firm Performance}

IC perform an essential role in the value creation and sustainable growth of the firm. It is in line with the resource-based theory (RBT), which explains that IC is the core of its value creation and competitive advantage (Barney, 1991). From the RBT perspective, creating a sustainable competitive advantage is closely related to the firm's ability to maintain asset resources that are valuable, rare and irreplaceable and allocate and deploy these resources effectively (Barney, 1991). Firms that have a sustainable competitive advantage will be able to win the competition in the market industry to create value and achieve optimal business performance.

Several previous studies examining the relationship between IC and firm performance managed to find the relationship between IC and firm performance. Chen et al. (2005) found that IC owned by a firm has a positive effect on market value and firm financial performance and can be an indicator for future financial performance. Meanwhile, Clarke et al. (2011) also found a direct relationship between IC and firm performance of firms listed in the Australian Stock Exchange. Several other studies have also found evidence that IC positively impacts firm performance (Tan et al., 2007; Firer \& Stainbank, 2003). Based on the above explanation, the hypotheses proposed in this study are as follows:

H1a: Intellectual capital positively related to the firm financial performance of high-technology firms in ASEAN.

H1b: Intellectual capital positively related to the firm market performance of high-technology firms in ASEAN. 


\subsection{Intellectual Capital, Family Ownership, and Firm Performance}

The firm's ability to grow and develop depends on its ability to use any available resources appropriately, both financial and physical and intellectual. Although the firm resources can be in the form of capital or financial resources, the intellectual resources are at each firm's core.

Consistent with the statement from Grant (1996), IC will not be able to provide an optimal competitive advantage without proper organization and allocation of the resource. According to RBT, the firm's ability to organize and manage resources nicely is one of the main requirements for the firm to create a competitive advantage from these resources. One of the most responsible for supervising the firm's activities management, including the activities of managing IC, is the firm's shareholders. As Keenan and Aggestam (2001) described, the attitude and expertise of substantial shareholders of the firm is the key to the implementation and accountability of firm management to guide the development, maintenance, and improvement of IC in the firm.

A previous study from Claessens et al. (2000) and Carney and Child (2013) found that firms in East Asia, including ASEAN, are firms which ownership is concentrated predominantly on family ownership. Consistent with the alignment effect on the family ownership of the firm, Anderson and Reeb (2003) showed that family firms are more efficient in terms of supervision and management of firm activity compared to firms that are widely held by the public. In the Asian context, Ng (2005) researched firms listed in the Hong Kong Stock Exchange (HSE), showed that the family ownership in Hong Kong and its collectivist culture would positively impact firm performance. Based on the explanations that have been described above, the hypotheses that can be proposed are as follows:

H2a: Family ownership can strengthen the positive relationship between intellectual capital and financial performance of high-technology firms in ASEAN.

H2b: Family ownership can strengthen the positive relationship between intellectual capital and market performance of high-technology firms in ASEAN.

\section{RESEARCH METHOD}

\subsection{Sample}

The sample in this study was obtained from the BvD OSIRIS database and company annual reports. The sample of this study is the firms engaged in high technology industries. The countries selected as the sample are the countries in Southeast Asia that have complete data for variables selected in the database OSIRIS, namely Indonesia, Malaysia, the Philippines, Singapore, and Thailand. The type of industry that is considered as the high-technology industry refers to the industrial classification based on the Standard Industrial Classification (SIC), namely:

- Computer hardware (SIC Codes 3570-3579)

- Electronic and other electrical equipment (SIC Codes 3610-3699)

- Photographic, optic and medical equipment (SIC Codes 3810-3873) 
- Communications (SIC Codes 4810-4899)

- Computer software (SIC Codes 7371-7379)

The initial sample consists of 375 firms with years of observations from 2008 to 2014. Periods of 2008 to 2014 are used because in those periods, ASEAN Economic Community is at the beginning phase, which is started to be considered the result of the ASEAN Economic Community Blueprint (2008), which is the result of the 13th ASEAN Summit in Singapore in 2007. AEC has been enacted actively by the end of 2015. So the data taken from 2008 to 2014 is to depict or demonstrate the firms need for IC role on firm performance at the beginning phase of AEC, which will be used to predict the importance of intellectual capital as one of the primary resources in competing and as the driver of success in the era of AEC.

Due to incomplete data on the variables selected, the final sample used in this study amounted to 317 firms with 1310 firm-year observations. From the table of sample distribution, it could be seen that Malaysia and Singapore have more high-technology firms than other countries. Table 1 shows the final sample used and its distribution by country and industry.

Table 1: Sample Distribution by Countries and Industries

\begin{tabular}{|c|c|c|c|c|c|c|}
\hline \multicolumn{7}{|l|}{ Panel A: Distribution by Countries } \\
\hline Number of Firm & & \multicolumn{5}{|c|}{ Number of Observation } \\
\hline Indonesia (IN) & 31 & & & & & 144 \\
\hline Malaysia (ML) & 115 & & & & & 475 \\
\hline Philippines $(\mathrm{PH})$ & 25 & & & & & 120 \\
\hline Singapura (SN) & 90 & & & & & 378 \\
\hline Thailand $(\mathrm{TH})$ & 56 & & & & & 193 \\
\hline Full sample & 317 & & & & & 1310 \\
\hline \multicolumn{7}{|l|}{ Panel B : Distribution by Industries } \\
\hline Industries & IN & ML & PH & SN & $\mathrm{TH}$ & $\begin{array}{l}\text { Full } \\
\text { Sample }\end{array}$ \\
\hline Communications & 18 & 14 & 11 & 13 & 13 & 69 \\
\hline Electronic and other electrical equipment & 2 & 47 & 5 & 49 & 32 & 135 \\
\hline Computer hardware & 1 & 2 & 1 & 10 & 4 & 18 \\
\hline Computer software & 9 & 45 & 8 & 12 & 7 & 81 \\
\hline Photographic, optic and medical equipment & 1 & 7 & 0 & 6 & 0 & 14 \\
\hline Total & 31 & 115 & 25 & 90 & 56 & 317 \\
\hline
\end{tabular}

\subsection{Variables}

a. Independent Variable

- Intellectual Capital (VAIC). IC was measured using VAIC, which was developed by Pulic (2000; 2004). Firer and Williams (2003) explained the advantages of the VAIC method, among others, VAIC provides a consistent and standardized measurement basis that allows an effective comparison analysis between companies and between countries; the data used in the VAIC calculation is based on data that has been audited in the financial statements so that the calculations will be more objective and reliable. In addition, VAIC has also been widely used in previous studies of IC (e.g., Clarke et al., 
2011; Maditinos et al., 2011; Chan, 2009; Tan et al., 2007; Chen et al., 2005; Firer \& Williams, 2003).

The following equation measures VAIC:

$$
V A I C_{t}=H C E_{t}+S C E_{t}+C E E_{t}
$$

Where:

VAIC $_{\mathbf{t}}=$ Value added intellectual coefficient at $\mathrm{t}$

HCE $_{\mathbf{t}} \quad=\mathrm{VA}_{\mathrm{t}} / \mathrm{HC}_{\mathrm{t}}$; human capital efficiency coefficient at $\mathrm{t}$

SCE $_{\mathbf{t}} \quad=\mathrm{SC}_{\mathrm{t}} / \mathrm{VAt}$; structural capital efficiency coefficient at $\mathrm{t}$

CEE $_{t} \quad=\mathrm{VA}_{\mathrm{t}} / \mathrm{CE}_{\mathrm{t}}$; capital employed efficiency coefficient at $\mathrm{t}$

VAt $\quad=$ OUT $_{t}-\mathrm{IN}_{\mathrm{t}}=\mathrm{OP}_{\mathrm{t}}+\mathrm{EC}_{\mathrm{t}}+\mathrm{D}_{\mathrm{t}}+\mathrm{A}_{\mathrm{t}}$; VA is the calculation of output $\left(\mathrm{OUT}_{\mathrm{t}}\right)$ calculated from total sales reduced by Input $\left(\mathrm{IN}_{\mathrm{t}}\right)$ calculated from bought-in materials or cost of goods or services sold; or it could be the calculation of operating income $\left(\mathrm{OP}_{\mathrm{t}}\right)$; employee costs $\left(\mathrm{EC}_{\mathrm{t}}\right)$; depreciation $\left(\mathrm{D}_{\mathrm{t}}\right)$; and amortization $\left(\mathrm{A}_{\mathrm{t}}\right)$

$\mathbf{H C}_{\mathbf{t}} \quad=$ total salaries and wages at $\mathrm{t}$

$\mathbf{S C}_{\mathbf{t}} \quad=\mathrm{VA}_{\mathrm{t}}-\mathrm{HC}_{\mathrm{t}}$; structural capital at $\mathrm{t}$

CE $_{t} \quad=$ book value of the net assets at $\mathrm{t}$

- Human Capital Efficiency (HCE). HCE is a component of VAIC that represents the efficiency of human capital or the ability to efficiently apply the skills and expertise (Pulic, 2000; 2004).

- Structural Capital Efficiency (SCE). SCE is a component of VAIC which represent the efficiency of structural capital and relational capital (Pulic, 2000; 2004).

- Capital Employed Efficiency (CEE). CEE is a component of VAIC that represent an efficient use of physical and financial capital (Pulic, 2000; 2004).

\section{b. Moderating Variable}

- Family Ownership (Fam_OWN). According to Villalonga and Amit (2006), a family firm is a firm whose family member by either blood or marriage is a director, or the owner of at least 5 per cent of the firm's equity, individually or as a group. Following the study from Villalonga and Amit (2006) and González and Meca (2014), family ownership in this study is measured by the proportion of family ownership in the ownership structure of the firm, i.e. the percentage of ownership that the family directly owns with a cut-off of $\geq 5$ per cent.

\section{c. Dependent Variable}

- Firm Performance (Firm_Perf). Same with the study from Chen et al. (2005), the firm performance is measured using two proxies, namely financial performance and market performance. The financial performance is measured by ROA (return on assets ratio), and the market performance is measured using MB (market capitalization ratio). The following equation calculates each proxy:

ROA = Profit before tax $/$ Average total assets .

MB = total market capitalization / book value of net assets. 


\section{d. Control Variable}

- Firm Size (FSize). Firm size is measured using the firm's total assets at year t, then the natural logarithm is calculated.

- Leverage (Lev). Leverage is calculated by dividing long-term liabilities by total assets.

- Years (Year). Years are proxied by dummy variables for each year of the study period, excluding one period. Year effects dummies for each of the years capture the influence of aggregate (time-series) trends. Therefore, a control for year effects is needed to make the coefficient becomes much more sensible.

\subsection{Regression Model}

This study uses panel data regression model analysis, namely fixed effect or random effect regression. This study uses the Hausman test to determine which is the most suitable panel data regression model between fixed and random effects.

The hypotheses testing in this study were using two-equation models. Model (1) was used to examine the relationship between IC and financial performance and the relationship between the interaction of IC and family ownership on the firm's financial performance. Meanwhile, model (2) is used to examine the relationship between IC and market performance and the relationship between the interaction of IC and family ownership on the market performance.

Hypothesis 1a is supported if the independent variable of $\beta_{1}$ VAIC is positively significant related to ROA. Meanwhile, hypothesis $1 \mathrm{~b}$ is supported if the independent variable of $\beta_{1}$ VAIC is positively significant related to MB. In the moderating variable hypothesis, hypothesis $2 \mathrm{a}$ is supported if the interaction of $\beta_{3}$ VAIC*Fam_OWN is positively significant related to ROA. In addition, hypothesis $2 \mathrm{~b}$ is supported if the interaction of $\beta_{3}$ VAIC*Fam_OWN is positively significant related to MB. The equation models used to test all of the hypotheses in this study are as follows:

Model 1. Interaction Model of VAIC and Family Ownership on Financial Performance

$$
\begin{aligned}
& \text { ROA }=\beta_{0}+\beta_{1} V A I C+\beta_{2} \text { Fam_OWN }_{-} \text {OW } \beta_{3} \text { VAIC } * \text { Fam_OWN }_{-} \text {OW } \beta_{4} \text { FSize }_{t}+ \\
& \beta_{5} \text { Lev }_{t}+\beta_{6} \operatorname{Year}_{t}+\varepsilon_{t}
\end{aligned}
$$

Model 2. Interaction Model of VAIC and Family Ownership on Market Performance

$$
\begin{aligned}
& M B=\beta_{0}+\beta_{1} V A I C+\beta_{2} F a m_{-} O W N+\beta_{3} V A I C * \text { Fam }_{-} O W N+\beta_{4} \text { FSize }_{t}+ \\
& \beta_{5} L e v_{t}+\beta_{6} \text { Year }_{t}+\varepsilon_{t}
\end{aligned}
$$

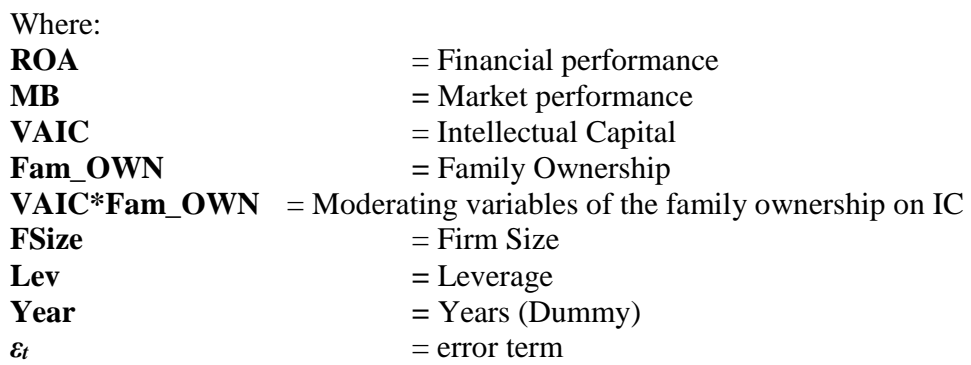




\subsection{Additional Analysis}

This study also conducted some additional analysis. Model (3) and (4) were used to examine the relationship between the components of IC and firm performance and the relationship between the interaction of IC components and family ownership on firm performance. This is done because previous studies found differences in the relationships between each component of IC on the firm performance (Firer \& Williams, 2003; Chen et al., 2005; Clarke et al., 2011; Maditinos et al., 2011).

In addition, testing is also performed for each country using models (1) and (2) as in the hypothesis testing to examine the relationship between IC on firm performance in each country and the relationship between the interaction of IC and family ownership on firm performance. In addition, the test is also performed for each country using models (3) and (4) to examine the relationship between the components of IC on firm performance and the relationship between the interaction of IC components and family ownership on firm performance in each country.

Model 3. Interaction Model of VAIC Components and Family Ownership on Financial Performance

$$
\begin{aligned}
& R O A=\beta_{0}+\beta_{1} H C E+\beta_{2} S C E+\beta_{3} C E E+\beta_{4} F a m_{-} O W N+\beta_{5} H C E *
\end{aligned}
$$

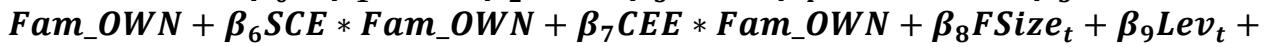

$$
\begin{aligned}
& \beta_{10} \operatorname{Year}_{t}+\varepsilon_{t}
\end{aligned}
$$

Model 4. Interaction Model of VAIC Components and Family Ownership on Market Performance

$$
\begin{aligned}
& M B=\beta_{0}+\beta_{1} H C E+\beta_{2} S C E+\beta_{3} C E E+\beta_{4} F a m_{-} O W N+\beta_{5} H C E * \text { Fam_OWN }+ \\
& \beta_{6} S C E * F a m_{-} O W N+\beta_{7} C E E * F a m_{-} O W N+\beta_{8} F_{\text {Size }}+\beta_{9} L e v_{t}+ \\
& \beta_{10} \operatorname{Year}_{t}+\varepsilon_{t}
\end{aligned}
$$

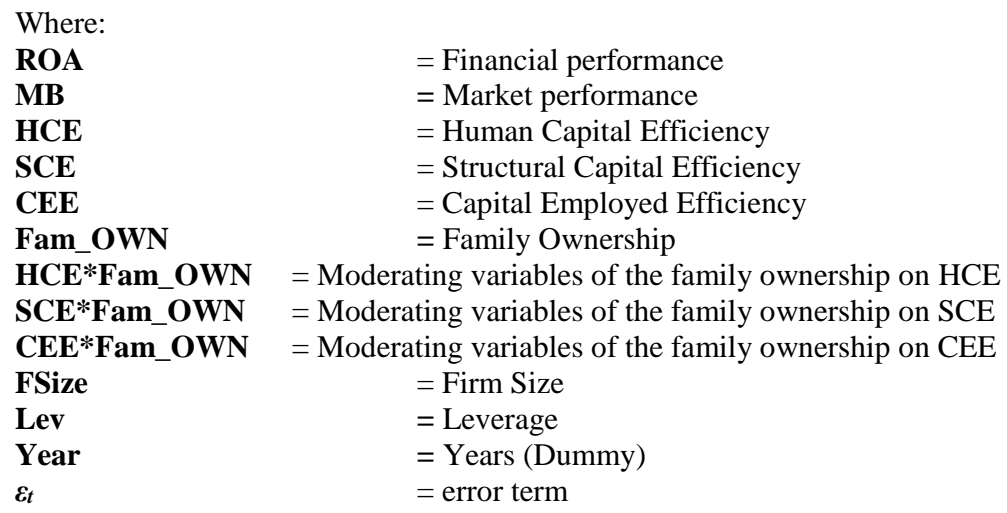




\section{RESULTS AND DISCUSSIONS}

\subsection{Descriptive Statistics}

Table 2 shows the descriptive statistics of the selected variables in this study. ROA has a mean value of 0.10742 , which indicates that the firms have fairly good profitability. Meanwhile, the variable MB has a mean value of 2.54007, implying that the firms have a pretty good market capitalization ratio value. VAIC, the proxy of the firm's intellectual capital, has a mean value of 6.20113. Meanwhile, the level of family ownership concentration of the sample firms ranged at 13.106 per cent. Overall, the descriptive statistics of each variable can be seen in Table 2 below.

Table 2: Descriptive Statistics of Selected Variables

\begin{tabular}{lrrrrr}
\hline \hline Variable & \multicolumn{1}{c}{ Minimum } & \multicolumn{1}{c}{ Maximum } & \multicolumn{1}{c}{ Mean } & \multicolumn{1}{c}{ Median } & \multicolumn{1}{c}{ Std. Dev. } \\
\hline ROA & 0.00028 & 1.14862 & 0.10742 & 0.08100 & 0.10246 \\
MB & 0.09093 & 220.61166 & 2.54007 & 1.13505 & 9.80251 \\
VAIC & 0.97753 & 291.18416 & 6.20113 & 3.88135 & 10.85719 \\
Fam_OWN & 0.00000 & 0.81420 & 0.13106 & 0.06270 & 0.17888 \\
FSize & 6.85569 & 17.28597 & 11.48533 & 11.29732 & 1.74279 \\
Total & 949.26 & 32151415.41 & 695658.44 & 80605.12 & 2688020.547 \\
Assets & 0.00000 & 0.71775 & 0.10527 & 0.05270 & 0.13236 \\
Lev & & & & & \\
\hline \hline
\end{tabular}

\subsection{Hausman test}

According to Gujarati and Porter (2009), research that uses panel data should be tested with panel data regression models. Therefore, this study uses the analysis of panel data regression models, namely fixed effect and random effect.

Gujarati and Porter (2009) explained that one of the methods that can be used to select fixed or random effects regression in the panel data regression model is to perform the Hausman test. In this study, the Hausman test was carried out with a confidence level of 5\%. Random effect regression is used if the p-value (Prob $>\mathrm{X}^{2}$ ) is greater than 0.05 . In the other condition, fixed effect regression would be an ideal model for conducting empirical analysis (Reyna, 2007).

Table 3 showed the overall results of the Hausman test. Based on the Hausman test results, this study used a fixed effect regression model to test hypotheses in equation model (1). It used a random effect regression model to test hypotheses in equation model (2). In addition, the Hausman test was also carried out to see which regression method was suitable for carrying out additional testing for the whole sample and the sample of each country. 
Table 3: Hausman Test for Hypothesis Testing and Additional Testing

\begin{tabular}{|c|c|c|c|c|}
\hline & Model 1 & Model 2 & Model 3 & Model 4 \\
\hline \multicolumn{5}{|c|}{ Full Sample } \\
\hline$X^{2}$ & 65.66 & 15.80 & 84.20 & 43.97 \\
\hline Prob $>X^{2}$ & 0.0000 & 0.1488 & 0.0000 & 0.0001 \\
\hline \multicolumn{5}{|l|}{ Indonesia } \\
\hline$X^{2}$ & 64.90 & 5.78 & 99.08 & 12.50 \\
\hline Prob $>X^{2}$ & 0.0000 & 0.8876 & 0.0000 & 0.6406 \\
\hline \multicolumn{5}{|l|}{ Malaysia } \\
\hline $\mathrm{X}^{2}$ & 24.98 & 14.73 & 65.72 & 113.49 \\
\hline Prob $>X^{2}$ & 0.0092 & 0.1953 & 0.0000 & 0.000 \\
\hline \multicolumn{5}{|l|}{ Philipina } \\
\hline$X^{2}$ & 9.61 & 28.14 & 57.43 & 42.85 \\
\hline Prob $>X^{2}$ & 0.5660 & 0.0031 & 0.0000 & 0.0002 \\
\hline \multicolumn{5}{|l|}{ Singapura } \\
\hline$X^{2}$ & 36.75 & 25.81 & 69.79 & 63.91 \\
\hline Prob $>X^{2}$ & 0.0001 & 0.0069 & 0.0000 & 0.0000 \\
\hline \multicolumn{5}{|l|}{ Thailand } \\
\hline $\mathrm{X}^{2}$ & 4.03 & 29.48 & 239.77 & 0.85 \\
\hline Prob $>X^{2}$ & 0.9690 & 0.0019 & 0.0000 & 1.0000 \\
\hline
\end{tabular}

\subsection{Hypotheses Testing}

\subsubsection{The Results of First Hypotheses Testing}

Hypotheses 1 of the study aims to answer whether there is a positive relationship between intellectual capital and firm performance. The firm performance is proxied by two proxies, namely financial performance and market performance. Therefore, hypothesis 1 is divided into two, namely hypotheses $1 \mathrm{a}$ and $1 \mathrm{~b}$.

Table 4 showed the results of overall hypothesis testing in this study. The result showed that VAIC has a significant positive impact on ROA or firm financial performance with a coefficient of 0.00390 at a significance level of 1 per cent. This indicates that if a firm can use its IC more efficiently, it can lead to improved firm's financial performance. Therefore, hypothesis 1a, which states that intellectual capital is positively related to the firm financial performance of hightechnology firms in ASEAN, is supported at the level of $\alpha=1$ per cent.

The result indicates that efficient and effective use of IC will lead the firm to achieve higher financial performance. The result of this study is consistent with previous studies conducted by Firer and Stainbank (2003), Chen et al. (2005), and Clarke et al. (2011), which found that intellectual capital is positively related to ROA, which is the proxy of firm financial performance.

Meanwhile, the hypothesis testing of hypothesis $1 \mathrm{~b}$ failed to find any relationship between VAIC and $\mathrm{MB}$, which is the proxy of market performance, as shown in Table 4. This indicates that the market does not consider the value of the intellectual capital of the firm. According to Holland and Johanson (2003), different capital markets may have a different focus on various aspects of firm 
performance and may consider or not consider the IC. There may be a difference between investors' awareness of IC importance in the firms' value creation, which may exist in different areas or countries where the capital markets are located. Thus, the impact of IC on market valuation may be different from a market in a country to another. This explains why some previous studies that also failed to find any relationship between intellectual capital and market performance have similar country characteristics. Research conducted by Firer and Williams (2003) in South Africa, Chan (2009) in Hong Kong, and Maditinos et al. (2011) in Greece are conducted in the similar characteristic of developing countries.

\subsubsection{The Results of Second Hypotheses Testing}

Hypotheses 2 of the study aims to answer the research question of whether family ownership can strengthen the relationship between intellectual capital and firm performance. As in hypothesis 1 , the hypotheses on hypothesis 2 are also split into hypotheses $2 \mathrm{a}$ and $2 \mathrm{~b}$. The results of testing the second hypothesis as a whole can be seen in Table 4.

The hypothesis testing of hypothesis $2 \mathrm{a}$ found that there is a significant negative impact of the interaction of VAIC*Fam_OWN on ROA with a coefficient of -0.00842 at a significance level of 1 per cent. This indicates that substantial family ownership in the firms can reduce the efficiency of IC utilization so that it would cause a decrease in the firm's financial performance. Therefore, hypothesis $2 \mathrm{a}$, which stated that family ownership could strengthen the positive relationship between intellectual capital and high-technology firms' financial performance in ASEAN, is not supported.

The result failed to support hypothesis $2 \mathrm{a}$ and was consistent with entrenchment effect views which explained that the family as controlling shareholders might take personal advantage of the firm at the expense of minority shareholders (Fama \& Jensen, 1983; Morck et al., 1988; Shleifer \& Vishny, 1997). Therefore, the entrenchment effect explains that the firm which ownership is concentrated predominantly on the family ownership may not be efficient and effective in monitoring and supervising the activities undertaken by management, including in supervising the maximum utilization of intellectual capital resources, which will lead the firm cannot be optimal in utilizing intellectual capital to achieve better performance. It implies that the firms with family ownership should strengthen the governance so that the entrenchment effect of the family ownership could be minimized. Therefore, the performance is not compensated by the entrenchment effect. Klein et al. (2005) found that some corporate governance mechanisms could be used to solve the agency problem of family firms so that it could hampering the entrenchment effect of family ownership. Reyna et al. (2012) also found that governance mechanisms could help keep align the interest of managers and shareholders, which is the family.

Meanwhile, the hypothesis testing of hypothesis $2 \mathrm{~b}$ failed to find any relationship between the interaction of VAIC*Fam_OWN and MB, which becomes a proxy of market performance as shown in Table 4. As described in the discussion of hypothesis $1 \mathrm{~b}$, this indicates that the market does not consider the value of the firm's intellectual capital, including for the firms whose ownership is concentrated predominantly on family ownership. 
Table 4: Hypotheses Testing Results

\begin{tabular}{lrr}
\hline \multirow{2}{*}{ Independent Variable } & \multicolumn{2}{c}{ Model 1 } \\
\cline { 2 - 3 } & \multicolumn{2}{c}{ Dependent Variable } \\
\cline { 2 - 3 } Const & 0.22496 & MB \\
& ROA & 1.28039 \\
VAIC & $(4.37)^{\beta}$ & $(0.63)$ \\
& 0.00390 & 0.35196 \\
Fam_OWN & $(8.12)^{\beta}$ & $(1.37)$ \\
& -0.04937 & 2.48382 \\
VAIC*Fam_OWN & $(-0.82)$ & $(0.92)$ \\
& -0.00842 & -0.73450 \\
FSize & $(-9.72)^{\beta}$ & $(-1.34)$ \\
& -0.00983 & -0.23092 \\
Lev & $(-1.95)$ & $(-1.15)$ \\
& -0.17946 & 7.40687 \\
Year & $(-17.21)^{\beta}$ & $(1.73)$ \\
$\mathbf{R}^{\mathbf{2}}$ Within & Included & Included \\
F & 0.1026 & 0.0735 \\
Prob $>$ F & 141.85 & \\
Wald $\mathbf{X}^{\mathbf{2}}$ & 0.0000 & 19.55 \\
Prob $>\mathbf{X}^{\mathbf{2}}$ & & 0.0518 \\
\hline \hline
\end{tabular}

Notes: $\beta$ indicates significant at the $1 \% ; \alpha$ indicates significant at the $5 \%$

Source: Output from STATA

\subsection{Additional Analysis}

This study also conducted some additional analysis. First, testing the relationship between components of IC individually and firm performance and the relationship between the interaction of IC components and family ownership on the firm performance of the firms operating in the hightechnology industry in ASEAN. This is done because previous studies found that there are differences in the relationships between each component of IC on the firm performance (Firer \& Williams, 2003; Chen et al., 2005; Clarke et al., 2011; Maditinos et al., 2011).

The results showed that the components of IC individually have different impacts on the firm performance, namely financial performance and market performance of the firms operating in the high-technology industry in ASEAN. The results show that Human Capital Efficiency (HCE) is not related to firm performance, both financial performance and market performance. Meanwhile, Structural Capital Efficiency (SCE) was positively related to financial performance but not related to market performance. On the other hand, Capital Employed Efficiency (CEE) is positively related to both proxies of the firm's performance.

In the moderating relationship, there is no relationship between HCE and family ownership on financial performance and market performance. The same for the relationship between the interaction of SCE and family ownership. Meanwhile, a positive relationship was found in the interaction of $\mathrm{CEE}$ and family ownership on financial performance, while for the market performance is found a negative relationship. Table 5 shows the whole results of additional testing for IC components with a full sample. 
Second, testing is also performed for each country to see the relationship between IC and firm performance in each country and the relationship between the interaction of IC and family ownership on firm performance. Table 6 displays the results of additional tests for each individual country as a whole.

Table 5: Additional Test Results for IC components

\begin{tabular}{lrr}
\hline \hline \multirow{2}{*}{ Independent Variable } & \multicolumn{2}{c}{ Model 4 } \\
\cline { 2 - 3 } Const & ROA & Dependent Variable \\
& & MB \\
HCE & 0.0492 & 4.40811 \\
& $(0.61)$ & $(0.90)$ \\
SCE & 0.00067 & 0.01316 \\
& $(1.56)$ & $(0.50)$ \\
CEE & 0.42503 & 0.00056 \\
& $(9.67)^{\beta}$ & $(0.00)$ \\
Fam_OWN & 0.00290 & 4.60796 \\
& $(3.55)^{\alpha}$ & $(7.34)^{\beta}$ \\
HCE*Fam_OWN & 0.03971 & 5.45011 \\
& $(0.30)$ & $(1.94)$ \\
SCE*Fam_OWN & -0.00197 & -0.05359 \\
& $(-2.23)$ & $(-0.92)$ \\
CEE*Fam_OWN & -0.36331 & 4.71215 \\
& $(-2.45)$ & $(1.27)$ \\
FSize & 0.40277 & -15.26845 \\
& $(5.73)^{\beta}$ & $(-4.23)^{\beta}$ \\
Lev & -0.018094 & -0.50742 \\
& $(-1.97)$ & $(-1.04)$ \\
Year & -0.15961 & -0.09923 \\
$\mathbf{R}^{2}$ Within & $(-8.98)^{\beta}$ & $(-0.07)$ \\
F & Included & Included \\
Prob > F & 0.3181 & 0.8129 \\
\hline \hline Notes: $\beta$ & 278.71 & 14.76 \\
\end{tabular}

Notes: $\beta$ indicates significant at the $1 \% ; \alpha$ indicates significant at the $5 \%$

Source: Output from STATA 


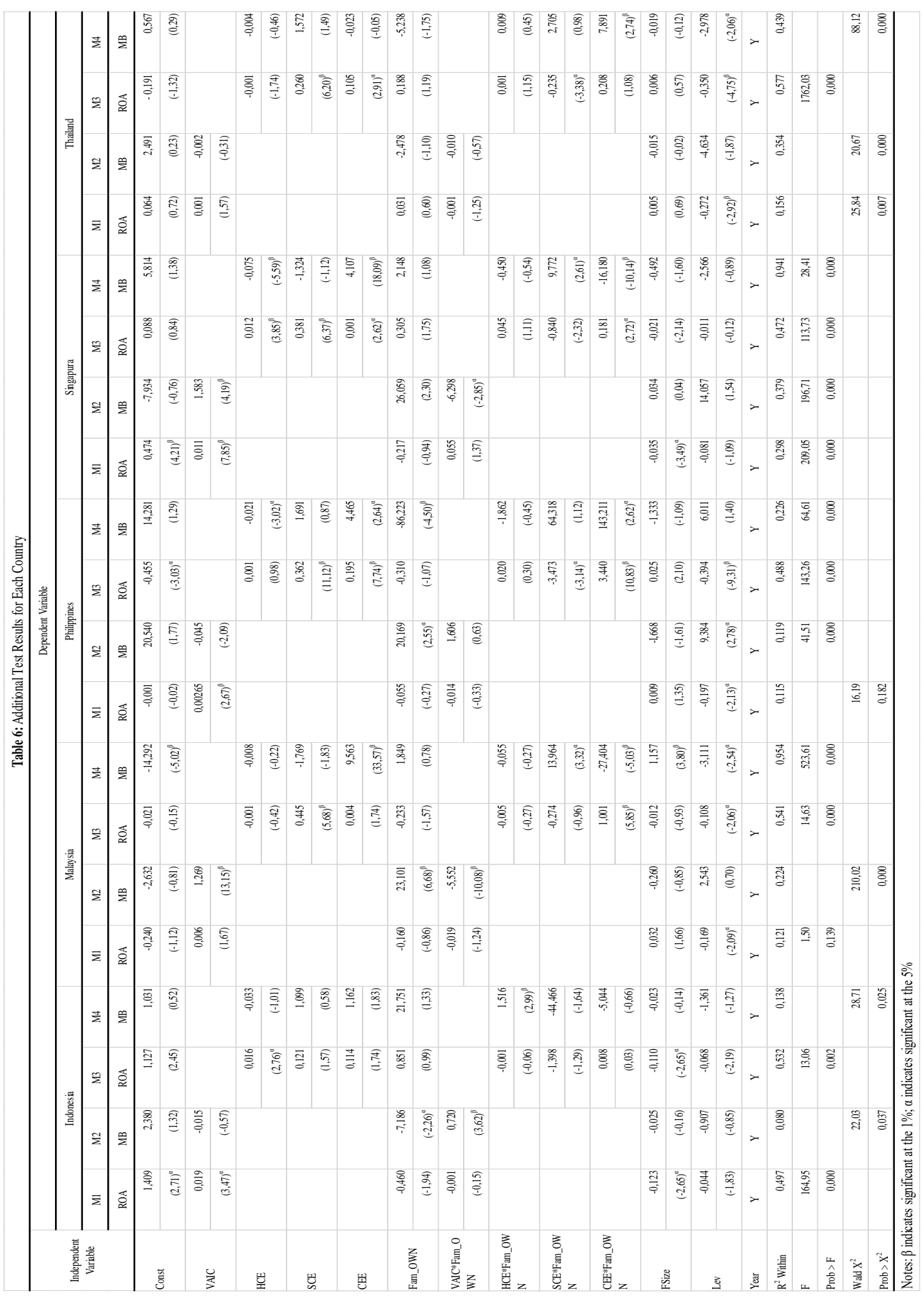




\section{CONCLUSIONS, LIMITATIONS, AND SUGGESTIONS}

\subsection{Conclusions}

The first objective of this study is to examine the positive impact of IC on the performance of the firms operating in the high-technology industry in ASEAN. The empirical results showed that intellectual capital has a positive impact on a firm financial performance. This indicates that efficient and effective use of intellectual capital will make the firm achieve higher financial performance. Firms are expected to effectively and efficiently manage and deploy their intellectual capital effectively and efficiently in facing ASEAN Economic Community challenges to make them competitive and successful. On the other hand, the results failed to support the relationship between intellectual capital and market performance. This indicates that the market does not consider the value of a firm's intellectual capital.

The second objective of this study was to examine whether family ownership can strengthen the relationship between intellectual capital and firm performance of the firms that operate in the hightechnology industry in ASEAN. The results showed that there is a significant negative impact between the interaction of intellectual capital and family ownership on the firm's financial performance. This is contrary to the hypothesis proposed and indicates that family ownership of the firms can reduce the efficiency of intellectual capital utilization by the firms so that it can decrease the firm's financial performance. This is consistent with the entrenchment effect views, which explained that the family ownership of the firms could lead to inefficient and ineffective in supervising and monitoring the activities undertaken by management, including in supervising the use of intellectual capital resources optimally, which will cause the firm to be not optimal in utilizing the intellectual capital to achieve better performance. It implies that the firms with family ownership should strengthen the governance so that the entrenchment effect of the family ownership could be minimized. Meanwhile, the results also failed to find evidence supporting the interaction of intellectual capital and family ownership on market performance.

\section{Limitations and Suggestions}

This study has several limitations. First, this study only uses samples of the firms that operate in the high-technology industry in ASEAN, so the results of this study may not be generalizable to firms with different industries. Further research can use several firms from various industries and compare them to determine the complete picture of the relationship between intellectual capital and firm performance from the standpoint of a more comprehensive range of industries.

Second, this study uses VAIC, a measurement of intellectual capital from accounting information of the firm. Further research can use another proxy for measuring the firm's intellectual capital by combining measurements of intellectual capital using monetary and non-monetary methods.

Finally, the implementation of the ASEAN Economic Community in late 2015 makes this study could not test the differences of the intellectual capital impact on firm performance between the period before the implementation of AEC and after the enactment of the AEC because of data limitations. Further research can add comparisons of ex-ante and ex-post AEC implementation to examine the impact of IC on the firm performance in the period before the enactment of AEC and after the enactment of AEC. 


\section{REFERENCES}

Anderson, R. C., \& D. M. Reeb. (2003). Founding-Family Ownership and Firm Performance: Evidence from the S\&P 500. Journal of Finance, 58(3), 1301-1328.

ASEAN Secretariat. (2008). ASEAN Economic Community Blueprint. Jakarta, Indonesia: ASEAN Secretariat.

Barney, J. B. (1991). Firm resources and sustained competitive advantage. Journal of Management, 17(1), 99-120.

Barney, J. B., Ketchen, D., \& Wright, M. (2011). The future of resource based theory: Revitalization or decline?. Journal of Management, 37(5), 1299-1315.

Bontis, N. (2001). Assessing knowledge assets: a review of the models used to measure intellectual capital. International Journal of Management Review, 3(1), 41-60.

Carney, R. W., \& Child, T. B. (2013). Changes to the ownership and control of East Asian corporations between 1996 and 2008: The primacy of politics. Journal of Financial Economics, 107(2), 494-513.

Chan, K. H. (2009). Impact of intellectual capital on organisational performance: An empirical study of companies in the Hang Seng Index (Part 1). The Learning Organization, 16(1), 4 21.

Chan, K. H. (2009). Impact of intellectual capital on organisational performance: An empirical study of companies in the Hang Seng Index (Part 2). The Learning Organization, 16(1), 2239.

Chen, M. C., Cheng, S. J., \& Hwang, Y. (2005). An empirical investigation of the relationship between intellectual capital and firms' market value and financial performance. Journal of Intellectual Capital, 6(2), 159-176.

Claessens, S., Djankov, S., \& Lang, L. H. P. (2000). The separation of ownership and control in East Asian Corporations. Journal of Financial Economics, 58(1-2), 81-112.

Clarke, M., Seng, D., \& Whiting, R. H. (2011). Intellectual capital and firm performance in Australia. Journal of Intellectual Capital, 12(4), 505-530.

Essen, M. V., Carney, M., Gedajlovic, E. R., \& Heugens, P. P. M. A. R. (2015). How does Family Control Influence Firm Strategy and Performance? A Meta-Analysis of US Publicly Listed Firms. Corporate Governance: An International Review, 23(1), 3-24.

Fama, E., \& Jensen, M. C. (1983). Separation of ownership and control. Journal of Law and Economics, 26(2), 301-325.

Firer, S., \& Stainbank, L. (2003). Testing the relationship between intellectual capital and a company's performance: Evidence from South Africa. Meditari Accountancy Research, 11 (1), 25-44.

Firer, S., \& Williams, S. M. (2003). Intellectual capital and traditional measures of corporate performance. Journal of Intellectual Capital, 4(3), 348-360.

González, J. S., \& García-Meca, E. (2014). Does Corporate Governance Influence Earnings Management in Latin American Markets. Journal of Business Ethics, 121(3), 419-440.

Grant, R. M. (1996). Toward a knowledge based theory of the firm. Strategic Management Journal, 17(2), 108-122.

Gujarati, D. N., \& Porter, D. C. (2009). Basic Econometrics (5 ${ }^{\text {th }}$ ed.). McGraw Hill/Irwin. New York, USA.

Hermans, R., \& Kauranen, I. (2005). Value creation potential of intellectual capital in biotechnology-empirical evidence from Finland. R\&D Management, 35(2), 171-185. 
Holland, J., \& Johanson, U. (2003). Value-relevant information on corporate intangibles - creation, use, and barriers in capital markets - "between a rock and a hard place". Journal of Intellectual Capital, 4(4), 465-486.

Isakov, D., \& Weisskopf, J. P. (2014). Are founding families special blockholders? An investigation of controlling shareholder influence on firm performance. Journal of Banking \& Finance, 41(1-2), 1-16.

Keenan, J., \& Aggestam, M. (2001). Corporate governance and intellectual capital: some conceptualisations. Corporate Governance: An International Review, 9(4), 259-275.

Klein, P., Shapiro, D., \& Young, J. (2005). Corporate Governance, Family Ownership and Firm Value: the Canadian evidence. Corporate Governance: An International Review,13(6), 769-784.

Kozlenkova, I. V., Samaha, S. A., \& Palmatier, R. W. (2014). Resource-based theory in marketing. Journal of the Academy of Marketing Science, 42(1), 1-21.

Maditinos, D., Chatzoudes, D., Tsairidis, C., \& Theriou, G. (2011). The impact of intellectual capital on firms' market value and financial performance. Journal of Intellectual Capital, 12(1), 132-151.

Morck, R., Shleifer, A., \& Vishny, R. (1988). Management Ownership and Market Valuation: An Empirical Analysis. Journal of Financial Economics, 20(1-2), 293-315.

Ng, C. Y. M. (2005). An Empirical Study on the Relationship Between Ownership and Performance in a Family-Based Corporate Environment. Journal of Accounting, Auditing \& Finance, 20(2), 121-146.

Peteraf, M., \& J. B. Barney. (2003). Unraveling the resource-based tangle. Managerial and Decision Economics, 24(4), 309-323.

Pulic, A. (2000). VAIC: an accounting tool for IC management. International Journal of Technology Management, 20(5-8), 702-714.

Pulic, A. (2004). Intellectual capital - does it create or destroy value?. Measuring Business Excellence, 8(1), 62-68.

Reyna, O. T. (2007). Panel data analysis: fixed and random effects using STATA. Princeton University. New Jersey, USA.

Reyna, J. M. S. M., Vázquez, R. D., \& Valdés, A. L. (2012). Corporate Governance, Ownership Structure and Performance in Mexico. International Business Research, 5(11), 12-27.

Shleifer, A., \& Vishny, R. (1997). A Survey of Corporate Governance. Journal of Finance, 52(2), 737-783.

Tan, H. P., Plowman, D. \& Hancock, P. (2007). Intellectual Capital and Financial Returns of Companies. Journal of Intellectual Capital, 8(1), 76-95.

Villalonga, B., \& Amit, R. (2006). How do family ownership, control and management affect firm value?. Journal of Financial Economics, 80(2), 385-417.

Wang, D. (2006). Founding Family Ownership and Earnings Quality. Journal of Accounting Research, 44(3), 619-656.

Wang, J. C. (2008). Investigating market value and intellectual capital for S\&P 500. Journal of Intellectual Capital, 9(4), 546-563. 